\title{
PENGARUH PENGGUNAAN INTERNET SEBAGAI SUMBER BELAJAR PADA MATERI PENGINDERAAN JAUH DAN SIG TERHADAP HASIL BELAJAR TENGAH SEMESTER GEOGRAFI KELAS XII IPS SMA NEGERI 21 MEDAN T.P. 2017 / 2018
}

\author{
Lambok A. Simanihuruk, Nahor M. Simanungkalit \\ Jurusan Pendidikan Geografi, Fakultas IImu Sosial, Universitas Negeri Medan \\ JI. Willem Iskandar Pasar V Medan, 20221, Indonesia \\ Email: lambokanthonius111@gmail.com
}

\begin{abstract}
Abstrak
Penelitian ini bertujuan untuk : (1) Untuk mengetahui bagaimana penggunaan internet sebagai sumber belajar pada materi penginderaan jauh dan sistem informasi geografi di kelas XII IPS SMA Negeri 21 Medan tahun ajaran 2017/2018. (2) Untuk mengetahui bagaimana pengaruh penggunaan internet sebagai sumber belajar terhadap hasil ujian tengah semester geografi pada materi penginderaan jauh dan sistem informasi geografi kelas XII IPS di SMA Negeri 21 Medan tahun ajaran 2017/2018. Penelitian ini dilaksanakan di kelas XII IPS SMA Negeri 21 Medan Tahun Pelajaran 2017/2018. Populasi dalam penelitian ini adalah seluruh siswa kelas XII IPS SMA Negeri 21 Medan sebanyak 124 siswa. Sampel dalam penelitian ini sebanyak 40 orang. Teknik pengumpulan data dalam penelitian ini adalah studi dokumenter dan komunikasi tidak langsung. Teknik analisis data yang digunakan yaitu Analisis Regresi Linear Sederhana, Uji determinan dan Pengujian Hipotesis secara Parsial (Uji t) dengan menggunakan aplikasi SPSS IBM 20. Hasil penelitian menunjukkan bahwa : (1). Penggunaan Internet sebagai Sumber belajar di SMA Negeri 21 Medan kelas XII IPS berada pada kategori sedang sebesar $65 \%$ dengan nilai 73- 105. (2) Pengaruh Penggunaan Internet sebagai Sumber belajar terhadap hasil belajar siswa, hal ini dibuktikan thitung sebesar 4,233. Dan apabila nilai thitung didistribusikan kepada ttabel dengan taraf signifikan 95\% dan a $=5 \%$ dengan $d k=40-1=39$ maka diperoleh $t_{\text {tabel }}$ 2,024. Dengan demikian thitung $>t_{\text {tabel }}(4,233>2,024)$, sehingga Penggunaan Internet sebagai Sumber belajar pada materi Penginderaan Jauh dan SIG berpengaruh signifikan terhadap hasil belajar tengah semester siswa kelas XII IPS SMA Negeri 21 Medan Tahun ajaran 2017/2018.
\end{abstract}

Kata kunci: sumber belajar, hasil belajar, SIG, Penginderaan Jauh

\section{PENDAHULUAN}

Proses pembelajaran merupakan bagian dari pendidikan formal dan sebuah proses komunikasi yang melibatkan guru, siswa, media, sumber belajar serta komponen lain yang mendukung dan juga merupakan suatu kegiatan melaksanakan kurikulum dalam suatu lembaga pendidikan, agar dapat mempengaruhi para siswa mencapai tujuan pendidikan yang telah ditetapkan. Dalam mencapai tujuan tersebut siswa berinteraksi dengan lingkungan belajar yang diatur guru melalui proses pembelajaran yang didalamnya mencakup kurikulum, tujuan, isi, bahan ajar, strategi belajar mengajar, media pembelajaran, sumber belajar dan evaluasi .

Dalam hal belajar, segala pengetahuan itu harus diperoleh dengan pengamatan sendiri, pengalaman sendiri, penyelidikan sendiri, bekerja sendiri, fasilitas yang diciptakan sendiri baik secara rohani maupun teknis.ini menunjukkan setiap orang yang belajar harus aktif sendiri. Tanpa ada aktivitas, proses belajar tidak mungkin terjadi. Sesuai dengan pandangan ini jelas bahwa dalam kegiatan belajar, subjek didik atau siswa harus aktif, karena tanpa aktivitas, proses belajar tidak mungkin berlangsung dengan baik.

Perubahan dan perkembangan yang berlaku dengan cepat, memerlukan penyediaan sumber belajar yang aktual, kaya informasi dan mudah terjangkau. Internet adalah teknologi yang telah memberikan landasan kuat bagi terciptanya lingkungan belajar yang kaya dan luwes, serta mampu memenuhi pendidikan dan latihan. Internet adalah jaringan dari jaringan, sebagaimana jaringan telepon yang mengkomunikasikan suara, internet mengkomunikasikan data. Sumber belajar dalam hal ini yaitu penggunaan internet yang dapat membantu siswa memperoleh segala informasi atau referensi mengenai materi pelajaran dalam proses pembelajaran (Sadiman dan Arief, 2009).

Terkait dengan sumber belajar, ada materi pelajaran yang memiliki karakteristik 
membutuhkan pemahaman yang cukup luas dan aktual dalam pemenuhan pemahaman topik tersebut oleh siswa. Pada umumnya materi pelajaran tersebut dalam hal penyampaian dan pengaplikasiannya kepada siswa membutuhkan internet sebagai sumber yang cukup tepat digunakan demi mengatasi keterbatasan alat ataupun fasilitas dalam menunjang pemenuhan materi tersebut.

Pada era globalisasi saat ini yang memiliki teknologi semakin canggih, belajar tidak hanya berlangsung di sekolah dengan menggunakan buku melainkan bisa dilakukan tanpa ada tatap muka (online). Pembelajaran tidak hanya terjadi di dalam kelas, dikarenakan pembelajaran bisa dilakukan secara mandiri oleh siswa tanpa harus bertatap muka dengan guru di kelas. Yang menjadi perhatian adalah bagaimana agar proses komunikasi itu berjalan dengan baik agar tujuan pembelajaran dapat tersampaikan secara utuh. Kecanggihan teknologi komunikasi memberi nuansa berbeda dalam proses belajar seseorang. Teknologi komunikasi mengubah lokasi belajar dari kelas ke tempat dimana saja peserta didik dapat belajar. la bisa mengakses internet untuk mempelajari isi atau topik pembelajaran. Teknologi komunikasi terutama belajar dunia maya dapat diakses dan diterapkan tanpa memandang usia, jarak, lokasi, karakteristik peserta didik. Dengan demikian teknologi telekomunikasi mendorong terjadinya evolusi pada belajar. Belajar tidak hanya lagi berlangsung di sekolah dan di kelas, belajar dapat terjadi dimana saja selama ada bahan ajar dan peserta didik merasa nyaman dengan tempat belajar itu, seperti di rumah, di warung internet, dan sebagainya.

Oleh karena hal tersebut, maka internet dijadikan sebagai sumber belajar sebagai salah satu bagian dari kecanggihan teknologi. Perkembangan teknologi dengan internet dalam pembelajaran berkembang cepat. Penggunaan internet sebagai sumber belajar sangat penting karena ada beberapa aplikasi internet yang memberi kemudahan dalam pembelajaran. Penggunaan internet sebagai sumber belajar sangat baik digunakan untuk membantu siswa memahami lebih luas pemahaman mengenai topik pembahasan pelajaran. Hal tersebut dikarenakan dalam pembelajaran, guru sering dihadapkan berbagai hal yang mengharuskan kita tidak bisa bertatap muka langsung dengan siswa. Di samping itu adanya internet sebagai sumber belajar dapat membantu membangun persepsi siswa bahwa mata pelajaran tersebut menarik untuk dipelajari. Namun pada kenyataannya, masih banyak siswa yang belum memanfaatkan internet dengan baik sesuai kebutuhannya sebagai peserta didik, contohnya masih banyak siswa yang memanfaatkan internet hanya untuk bermain games online berjam-jam, facebook, dan media sosial lainnya.

Bagi para pendidik dan peserta didik, internet merupakan sumber ilmu pengetahuan yang selalu baru. Banyak artikel dan bahasan menarik yang dapat dijumpai di dalamnya. Penggunaan internet merupakan cara untuk mendapatkan ilmu pengetahuan, penunjang yang dapat meningkatkan dan mengembangkan ilmu yang telah atau akan diminati seseorang. Seseorang menggunakan internet akan mendapatkan pengetahuan yang diminatinya. Banyak sekali informasi-informasi yang tersimpan dalam internet baik lokal maupun internasional. Internet sebagai suatu jaringan global yang menampung jutaan atau bahkan milyaran informasi digunakan orang sebagai sumber untuk belajar berbagai hal baik secara otodidak maupun dengan fasilitator. Satu bentuk teknologi pendidikan adalah internet yang berkembang pesat di penghujung abad 20 dan di ambang abad 21. Kehadirannya telah memberikan dampak yang cukup besar terhadap kehidupan umat manusia dalam berbagai aspek dan dimensi. Internet merupakan salah satu instrumen dalam era globalisasi yang telah menjadikan dunia ini menjadi transparan dan terhubung dengan sangat mudah dan cepat tanpa mengenal batas batas kewilayahan atau kebangsaan (Oetomo, 2002) .

Sumber belajar melalui internet merupakan imbas dari teknologi yang berkembang saat ini. Semua hal yang berhubungan dengan bahan pelajaran akan terangkum dalam sebuah aplikasi dalam internet. Internet juga mampu menjangkau pembelajaran jarak jauh. Kehadiran teknologi internet yang meluas di seluruh dunia, setiap guru atau siswa mampu berdiskusi dan berinteraksi dengan baik dengan guru atau siswa di belahan negara lain. Penggunaan internet sebagai sumber belajar saat ini juga sangat dianjurkan demi tercapainya pembelajaran dan memberikan berbagai wawasan tentang berbagai kemudahan aplikasi dalam internet yang berkaitan dengan pembelajaran. Ada enam fungsi internet yang dimanfaatkan dalam kehidupan sehari-hari yaitu fungsi sebagai alat komunikasi, sebagai alat mengakses informasi, fungsi pendidikan dan pembelajaran, serta fungsi tambahan (suplemen), fungsi pelengkap (komplemen), dan fungsi pengganti (Kenji Kitao dalam Munir, 2008).

Geografi sebagai salah satu mata pelajaran yang membahas tentang permukaan bumi serta 
gejalanya memiliki karakteristik membutuhkan informasi dan sumber-sumber yang akurat, aktual dan terbaru dalam pemenuhan materinya sehingga membutuhkan sumber belajar seperti Internet. Penginderaan Jauh dan SIC dalam mata pelajaran geografi merupakan materi yang membutuhkan sumber yang aktual dan terbaru dalam mendapatkan informasi tentang foto-foto permukaan bumi serta gejalanya dan informasi mengenai cara mengidentifikasi hasil yang didapat untuk dikomunikasikan dari guru kepada siswa atau siswa kepada siswa untuk pemahaman cukup lengkap tentang materi penginderaan jauh dan SIC tersebut.

Berdasarkan hasil penelitian Mudiyanah (2015) tentang pengaruh pemanfaatan internet terhadap hasil belajar diperoleh terdapat pengaruh signifikan dengan interpretasi yang cukup atau sedang antara pemanfaatan internet dengan hasil belajar siswa di MA Plus Peradaban Insani Batuceper Tangerang, memiliki persentase $20,52 \%$ dan $79,48 \%$ berasal dari faktor lain.

Selanjutnya Damanik dan Hutabarat (2016) mengemukakan bahwa, pemanfaatan media internet dalam bentuk blog pada pembelajaran sistem informasi geografis di Jurusan Pendidikan Geografi Universitas Negeri Medan dapat meningkatkan ketuntasan belajar dari $62,2 \%$ menjadi $100 \%$ pada siklus 1 dan siklus 2 .

SMA Negeri 21 Medan merupakan salah satu sekolah Negeri yang terletak Kecamatan Medan Amplas. Berdasarkan observasi awal dan wawancara dengan siswa, didapat seluruh siswa kelas XII IPS dapat mengakses internet dari fasilitas yang dimiliki secara pribadi maupun didapat pada fasilitas umum baik dalam segi hiburan, media sosial, mengerjakan tugas dan berkomunikasi .Hasil belajar juga didapat bahwa pada hasil belajar siswa kelas 12 IPS yang tidak lulus KKM( Kriteria Ketuntasan Minimum) yakni 75 yang telah ditetapkan oleh sekolah. Total jumlah seluruh kelas XII IPS di SMA Negeri 21 Medan yang berjumlah 124 siswa terdapat sekitar $20 \%$ tidak lulus KKM. Adapun rincian persentase siswa yang tidak lulus kriteria ketuntasan minimum (KKM) di kelas XII IPS 1 sebesar 19\%, kelas XII IPS 2 sebesar 24\%, kelas XII IPS 3 sebesar 16\% dan kelas XII IPS 4 sebesar 22\%.

Berdasarkan uraian diatas tersebut, mendorong untuk dilakukannya penelitian guna melihat bagaimana pengaruh penggunaan internet sebagai sumber belajar geografi pada materi penginderaan jauh dan SIC terhadap hasil belajar tengah semester geografi Kelas XII IPS SMA Negeri 21 Medan T.P.2017/2018.

\section{METODE PENELITIAN}

Penelitian ini akan dilaksanakan di kelas XII IPS SMA Negeri 21 Medan Tahun Pelajaran $2017 / 2018$. Penelitian ini akan dilaksanakan pada semester ganjil. Alasan pemilihan lokasi ini yaitu (1) penggunaan internet sebagai sumber belajar kelas XII IPS di SMA Negeri 21 Medan (2) Hasil belajar siswa dalam menggunakan internet sebagai sumber belajar.

Populasi dalam penelitian ini adalah seluruh siswa kelas XII IPS SMA Negeri 21 Medan yang terdiri dari empat (4) kelas yaitu kelas XII IPS 1, XII IPS 2, XII IPS 3, XII IPS 4. Dimana jumlah siswa kelas XII IPS SMA Negeri 21 Medan yaitu 124 siswa. Sampel dalam penelitian ini adalah $30 \%$ dari seluruh jumlah populasi yaitu sebanyak 38 orang. Teknik pengambilan sampel yang digunakan dalam penelitian ini adalah proporsional random sampling yaitu dari jumlah populasi ditentukan jumlah sampel sebagai objek penelitian, pengambilan sampel dilakukan secara merata ke setiap kelas sehingga semua responden mempunyai kesempatan yang sama sebagai sampel penelitian. Sampel dalam penelitian ini tertera pada tabel 1 berikut:

\begin{tabular}{ccccc}
\multicolumn{5}{c}{ Tabel 1. Sampel Penelitian } \\
\hline No & Kelas & $\begin{array}{c}\text { Jumlah } \\
\text { (orang) }\end{array}$ & Rumus & $\begin{array}{c}\text { Sampel } \\
\text { (orang) }\end{array}$ \\
\hline 1 & XII IPS 1 & 29 & $29 \times 30 \%$ & 10 \\
2 & XII IPS 2 & 31 & $31 \times 30 \%$ & 10 \\
3 & XII IPS 3 & 32 & $32 \times 30 \%$ & 10 \\
4 & XII IPS 4 & 32 & $32 \times 30 \%$ & 10 \\
\hline Jumlah & 124 & & 40 \\
\hline \multicolumn{5}{c}{ Sumber: Analisis data, 2017 }
\end{tabular}

Penelitian ini memiliki instrumen penilaian berupa angket penggunaan internet sebagai sumber belajar yang harus diuji terlebih dahulu. Pengujian instrumen penilaian tersebut menggunakan beberapa cara seperti berikut:

a. Validitas

Dihitung dengan menggunakan rumus korelasi product moment dengan angka kasar (Arikunto, 2006:170):

$r_{\mathrm{xy}}=\frac{\mathrm{N} \Sigma \mathrm{X}-\sum \mathrm{XN} \Sigma \mathrm{Y}-\sum \mathrm{Y}}{\mathrm{N} \Sigma \mathrm{XY}-\sum \mathrm{X} \Sigma \mathrm{Y}}$

Keterangan:

Rxy : Koefisien korelasi antara variabel $X$ dan variabel $Y$

$X \quad$ : Skor item setiap nomor pernyataan

$\mathrm{Y}:$ : Skor total setiap peserta

$\mathrm{N}$ : Jumlah peserta

b. Analisis reliabilitas

Angket dalam penelitian mempunyai skor antara 1-4, maka perhitungan reliabilitas menggunakan rumus alpha (Arikunto, 2006:196). Rumusnya adalah sebagai berikut: 
Keterangan:

$$
\mathrm{r}_{11}=\left(\frac{\mathrm{k}}{(\mathrm{k}-1)}\right)\left(1-\frac{\sum \sigma \mathrm{b}^{2}}{\left(\sigma \mathrm{t}^{2}\right)}\right)
$$

r11 : Reliabilitas instrumen

k : Banyaknya butir angket

$\Sigma \sigma b^{2} \quad$ : jumlah varians butir

$\sigma \mathrm{t}^{2} \quad$ : varians total

Untuk mengetahui bagaimana pengaruh antara kedua variabel bebas $X$ (Penggunaan Internet sebagai Sumber Belajar) terhadap variabel terikat $Y$ (Hasil belajar) dapat digunakan rumus analisis regresi linear sederhana.

Rumus Regresi Linear sederhana oleh Sudjana (2005) sebagai berikut:

$$
\begin{aligned}
& Y=\boldsymbol{\alpha}+\boldsymbol{b} X \\
& \boldsymbol{a}=\frac{\left(\sum Y\right)\left(\sum X^{2}\right)-\left(\sum X\right)\left(\sum X Y\right)}{n \cdot \sum X^{2}-\left(\sum X\right)^{2}} \\
& \boldsymbol{b}=\frac{n \cdot \sum X Y-\left(\sum X\right)\left(\sum Y\right)}{n \cdot\left(\sum X^{2}\right)-\left(\sum X\right)^{2}}
\end{aligned}
$$

Keterangan :

$X \quad$ : Variabel bebas (Penggunaan internet sebagai sumber belajar)

Y : Variabel terikat (Hasil Belajar siswa)

a dan b : Konstanta

$\mathrm{n} \quad$ : Jumlah sampel

Untuk mengetahui kontribusi penggunaan internet sebagai sumber belajar (X) terhadap Hasil Belajar ( $Y$ ) digunakan rumus determinasi sebagai berikut:

$$
\mathrm{R}^{2}=\frac{b\left(n \sum X Y-\left(\sum X\right)\left(\sum Y\right)\right)}{n \sum Y^{2}-\left(\sum Y\right)^{2}}
$$

Keterangan :

$\mathrm{R}^{2}$ : Kontribusi variabel bebas

$X$ : Variabel bebas (penggunaan internet sebagai sumber belajar)

Y : Variabel terikat (Hasil Belajar siswa)

$\mathrm{n}$ : Jumlah sampel

b : Konstanta

Untuk menentukan hubungan yang terjadi diantara kedua variabel diatas, maka ditentukan dengan menggunakan uji "t" yaitu :

$$
t=r \frac{\sqrt{n-2}}{1-r^{2}}
$$

(Sugiyono, 2008)

Keterangan :

$\mathrm{T} \quad$ : Uji t

$\mathrm{R}$ : Nilai kolerasi sederhana

$\mathrm{N}$ : Jumlah sampel

1 : Nilai Konstanta

N-2 : Derajat bebas

Selanjutnya untuk menghitung hipotesis, apabila harga $t$ hitung yang diperoleh lebih besar dari $t_{\text {tabel }}$ untuk tingkat kesalahan 5\% ( $t_{\text {hitung }}>$ $t$ tabel) maka hipotesis alternatif ( $\mathrm{Ha}$ ) diterima, sebaliknya apabila harga $t$ hitung yang diperoleh lebih kecil dari $\mathrm{t}$ hitung ( $\left.t_{\text {hitung }}>t_{\text {tabel }}\right)$ maka hipotesis alternatif $(\mathrm{Ha})$ ditolak.

\section{HASIL DAN PEMBAHASAN}

\section{Penggunaan Internet Sebagai Sumber Belajar Siswa Kelas XII IPS SMA N 21 Medan}

Penggunaan internet sebagai sumber belajar terdiri dari meningkatkan pengetahuan, meningkatkan komunikasi, menambah wawasan, sumber informasi, belajar interaktif. Penggunaan internet sebagai sumber belajar terhadap hasil belajar siswa sangat penting, karena dapat membantu siswa dalam berbagai pengetahuan baik bidang pendidikan maupun bidang lainnya. Internet juga dapat membantu siswa dalam meningkatkan aktivitas belajar siswa yang semakin baik dan akan mempengaruhi hasil belajar siswa tersebut.

Dengan kemajuan teknologi melalui internet siswa bisa belajar sendiri tanpa adanya guru, bahkan siswa diajarkan lebih mandiri dalam belajar. dengan Penggunaan Internet sebagai Sumber belajar akan membuat siswa lebih aktif dalam belajar, karena banyak terdapat berbagai video, maupun animasianimasi yang dapat diperagakan oleh siswa dan membuat siswa lebih mudah mengerti dalam belajar.

Mengacu pada pernyataan tersebut diketahui bahwa penggunaan internet sebagai sumber belajar di SMA Negeri 21 Medan kelas XII IPS didominasi oleh kategori sedang sebesar $65 \%$ dengan nilai $73-105$, selebihnya $12,5 \%$ kategori rendah dengan nilai $<73$ dan sebesar $22,5 \%$ tergolong kategori tinggi dengan nilai $\geq 106$. Lebih lanjut dapat dilihat pada Tabel 2 berikut.

Tabel 2. Kategori Penggunaan Internet Sebagai Sumber belajar Tahun 2018

\begin{tabular}{ccccc}
\hline No & $\begin{array}{c}\text { Interval } \\
\text { Kelas }\end{array}$ & $\begin{array}{c}\mathrm{F} \\
\text { Absolut }\end{array}$ & $\begin{array}{c}\mathrm{F} \\
\text { Relatif }\end{array}$ & Kategori \\
\hline 1 & $\geq 106$ & 9 & $22,5 \%$ & Tinggi \\
\hline 2 & $73-105$ & 26 & $65 \%$ & Sedang \\
\hline 3 & $<73$ & 5 & $\begin{array}{c}12,5 \\
\%\end{array}$ & Rendah \\
\hline \multicolumn{5}{c}{ Sumber : Hasil Penelitian, 2017 }
\end{tabular}

Distribusi frekuensi jawaban angket Penggunaan Internet sebagai Sumber belajar menunjukkan hasil tertinggi diperoleh melalui indikator penggunaan dan ketersediaan internet dengan hasil 2,95 tergolong kategori baik, belajar interaktif dengan hasil 2,60 tergolong kategori baik, internet sebagai sumber informasi dengan hasil 2,55 tergolong kategori baik, internet sebagai sumber belajar alternatif dengan hasil 2,52 tergolong baik, internet meningkatkan komunikasi dengan hasil 
2,47 tergolong kategori baik dan internet meningkatkan pengetahuan dengan hasil 2,39 tergolong kategori baik.

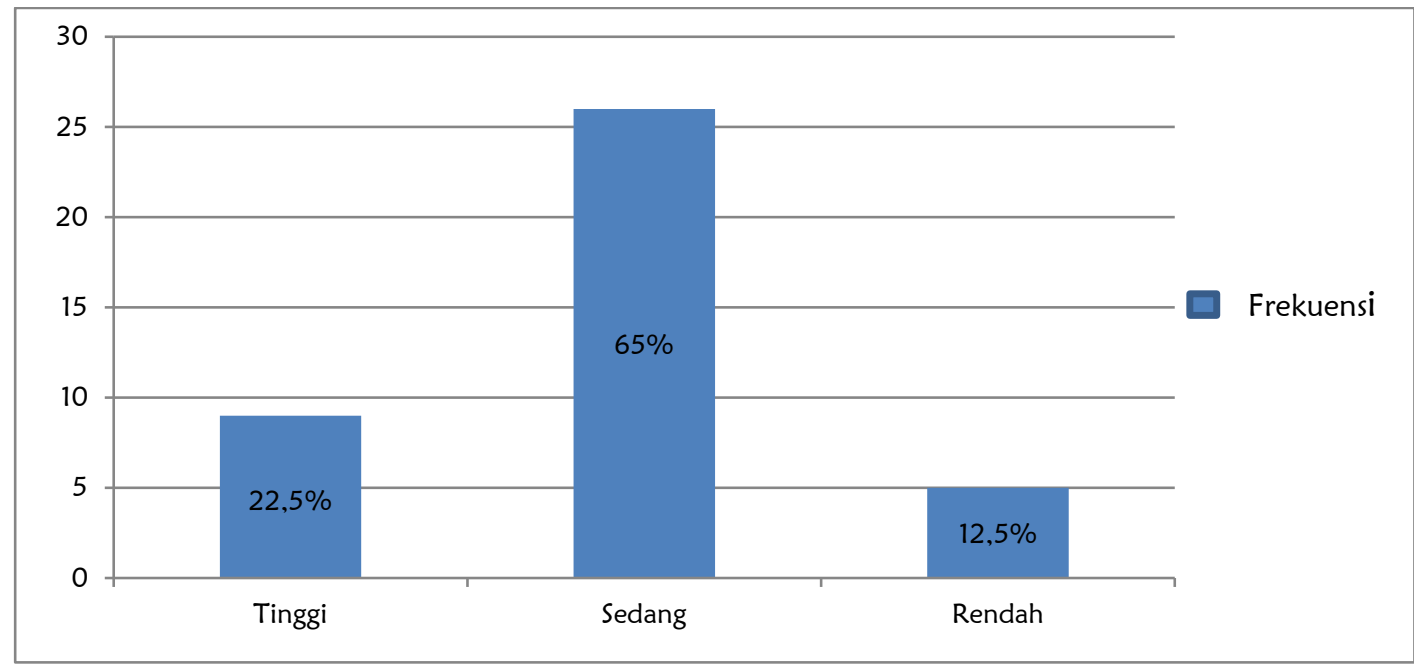

Gambar 1. Diagram Skor Angket Penggunaan Internet Sebagai Sumber Belajar Kelas XII IPS SMA Negeri 21 Medan

Distribusi frekuensi angket penggunaan internet sebagai sumber belajar, bahwa indikator penggunaan dan ketersediaan internet sebagai sumber informasi memperoleh nilai tertinggi dari seluruh indikator dengan hasil 2,95. Indikator internet sebagai belajar interaktif memperoleh nilai tertinggi ketiga dengan hasil 2,60, dengan perolehan tersebut siswa kelas XII IPS SMA Negeri 21 Medan menyatakan bahwa dengan menggunakan internet siswa memanfaatkannya dalam kegiatan diskusi kelompok pada materi SIC, siswa memanfaatkan aplikasi youtube dan mengunduh topik tentang mengidentifikasi objek-objek permukaan bumi dalam penginderaan jauh dan pengenalan SIG, siswa terbantu dalam meningkatkan aktivitas belajar dalam hal bertanya dan menjawab kepada guru, dan dengan internet siswa terbantu dalam meningkatkan hasil ujian geografi. Sedangkan indikator internet sebagai sumber informasi memperoleh nilai tertinggi kedua dengan hasil 2,55, dengan perolehan tersebut siswa kelas XII IPS SMA Negeri 21 Medan menyatakan bahwa dengan menggunakan internet sangat membantu mereka mendapatkan informasi tentang proyeksi peta dalam bidang datar, jenis-jenis peta, komponen-komponen SIC dan cara mengidentifikasi hasil penginderaan jauh. Internet sebagai Sumber Belajar Alternatif memperoleh nilai tertinggi keempat dengan hasil 2,52, dengan perolehan tersebut siswa kelas XII IPS SMA Negeri 21 Medan menyatakan bahwa dengan menggunakan internet, siswa mencari materi bacaan tentang komponenkomponen peta, teknik membuat peta, pengertian penginderaan jauh, unsur-unsur citra penginderaan jauh, membaca artikel manfaat SIC dalam ilmu geografi dan dalam kehidupan sehari-hari, dan mencari jawaban tugas tentang peta dan penginderaan jauh. Indikator internet Meningkatkan Pengetahuan memperoleh hasil 2,39, dengan perolehan tersebut siswa kelas XII IPS SMA Negeri 21 Medan menyatakan bahwa siswa cukup terbantu dengan sajian langkah-langkah membuat peta di internet, pengetahuan tentang klasifikasi peta

Dan indikator internet sebagai Komunikasi memperoleh hasil 2,41, dengan perolehan tersebut siswa kelas XII IPS SMA Negeri 21 Medan menyatakan bahwa siswa lebih cenderung berada pada kategori kadangkadang dalam membicarakan atau membahas topik pelajaran geografi pada saat menggunakan internet melalui media sosial ataupun chatting.

Hal ini sejalan dengan yang dikemukakan Darmawan (2014) yakni Penggunaan internet adalah sebagai Sumber belajar. Peran internet dalam pemanfaatannya untuk pendidikan dari yang awalnya sebagai sistem dan atau peralatan elektronik bergeser menjadi media penyalur pesan pendidikan. Karena internet memiliki peran sebagai Sumber belajar, dan Sumber belajar dapat berfungsi sebagai sumber belajar, berarti internet dapat berfungsi sebagai sumber belajar. Internet sebagai sumber belajar dapat dimanfaatkan siswa dalam kegiatan belajar- 
mengajar atau dalam proses belajarnya. Siswa dapat dengan mudah mengakses informasiinformasi yang dibutuhkan demi menunjang proses belajar. Munir (2008: 132) mengemukakan jenis-jenis sumber belajar yang dapat digunakan oleh pengajar maupun siswa salah satunya adalah Internet, dengan jaringan kerjanya (network) merupakan sumber untuk mendapatkan segala macam bahan ajar yang bisa dicetak atau digandakan.

\section{Pengaruh Penggunaan Internet Sebagai Sumber Belajar Terhadap Hasil Belajar Siswa}

Dari hasil penelitian diketahui secara umum Penggunaan Internet sebagai Sumber belajar terhadap hasil belajar siswa, maka diperoleh $t_{\text {hitung }}$ sebesar 4,134. Dan apabila nilai $t_{\text {hitung }}$ didistribusikan kepada $t_{\text {tabel }}$ dengan taraf signifikan 95\% dan a $=5 \%$ dengan $\mathrm{dk}=40-2$ $=38$ maka diperoleh $t_{\text {tabel }}$ 2,024. Dengan demikian $t_{\text {hitung }}>t_{\text {tabel }}(4,134>2,024)$, sehingga dapat disimpulkan bahwa variabel Penggunaan Internet sebagai Sumber belajar berpengaruh positif dan signifikan terhadap hasil belajar siswa kelas XI IIS pada mata pelajaran geografi di SMA Negeri 21 Medan Tahun ajaran 2017/2018.

Hasil penelitian ini sejalan dengan penelitian yang dilakukan Saddam (2013), Hasil penelitian hipotesis alternatif $(\mathrm{Ha})$ diterima yaitu ada pengaruh internet terhadap hasil belajar siswa kelas XI pada Mata Pelajaran PKN di SMA Swasta Eria Medan Semester Genap Tahun Pelajaran 2012/2013, dan hipotesis Nilai (Ho) ditolak yakni tidak ada pengaruh internet terhadap hasil belajar siswa siswa kelas XI pada Mata Pelajaran PKN di SMA Swasta Eria Medan Semester Genap Tahun Pelajaran 2012/2013.

Hal ini juga sesuai dengan teori yang dikemukakan Gordin (1995), menyatakan bahwa "Penggunaan Internet sebagai Sumber belajar siswa tidak terbatas oleh waktu seperti halnya tatap muka biasa, melalui internet Pembelajaran dapat memilih topik atau bahan ajar yang sesuai dengan keinginan dan kebutuhan masing-masing, Pembelajaran dapat dilakukan secara interaktif, sehingga menarik siswa dan memungkinkan pihak berkepentingan (orang tua siswa maupun guru) dapat turut serta menyukseskan proses pembelajaran, dengan cara mengecek tugastugas yang dikerjakan siswa secara online”.

Jadi dapat dikatakan bahwa penggunaan internet sebagai sumber belajar geografi terutama dalam materi Peta, Penginderaan Jauh dan SIC, dapat meningkatkan hasil belajar siswa karena dapat merangsang pengetahuan dan informasi siswa tentang materi-materi geografi terutama materi penginderaan jauh dan SIC yang sangat membutuhkan peran internet sebagai sumber belajar dalam menggali pemahaman lebih jauh dengan melihat contohcontoh citra penginderaan jauh dan hasil perekaman objek di permukaan bumi. Hal itu dikarenakan internet menyediakan beberapa aplikasi ataupun fitur-fitur yang berkaitan tentang materi penginderaan jauh dan SIG, contohnya adalah Google Earth dan Google Maps.

Internet dapat tepat dan efektif untuk dijadikan sebagai sumber belajar. Internet yang dijadikan sebagai sumber belajar diharapkan dapat mengatasi keterbatasan ruang dan daya indera bagi siswa yang dapat menimbulkan semangat dan kemudahan dalam belajar, sehingga hasil belajar siswa dapat meningkat.

Penggunaan internet sebagai sumber belajar dapat memenuhi kriteria suatu sumber belajar yang memberikan pengaruh lebih besar terhadap kehidupan siswa, sebab internet memungkinkan siswa untuk melihat dan mendengar secara langsung apa yang ingin diketahui dan dipelajari sehingga dapat memberikan efek atau pengaruh yang nyata terhadap diri siswa khususnya saat siswa itu belajar.

Selain itu esensi dari penggunaan internet sebagai sumber belajar ialah dapat memperbaiki muatan atau isi dari bagian kurikulum geografi yang diajarkan, dengan kata lain menggunakan internet sebagai salah satu sumber belajar maka bagian yang menjadi kurikulum geografi dapat dimengerti dan dipahami siswa seperti materi yang dianggap abstrak oleh siswa dapat menjadi lebih konkret dengan melalui pemahaman secara langsung oleh siswa dan sekaligus menciptakan atau meningkatkan daya kritis siswa terhadap materi geografi khususnya pada materi Penginderaan Jauh dan SIC.

Hal lain yang dapat dijadikan sebagai bahan pertimbangan mengenai keefektifan internet sebagai sumber belajar dibandingkan sumber belajar lainnya. Internet dapat digunakan menolong siswa dalam menentukan dan menginterpretasi fakta-fakta secara objektif. Dapat ditarik kesimpulan bahwa internet adalah sesuatu yang sangat berpengaruh dalam di dalam ataupun di luar proses pembelajaran terutama pada pelajaran geografi materi penginderaan jauh dan SIG, sehingga para siswa yang memanfaatkan internet sebagai sumber belajar cenderung lebih baik hasil belajar geografinya daripada yang tidak memanfaatkannya. 


\section{KESIMPULAN}

Berdasarkan pembahasan maka diperoleh kesimpulan sebagai berikut:

1. Penggunaan internet sebagai sumber belajar siswa kelas XII IPS Mata pelajaran geografi pada materi Penginderaan jauh dan Sistem Informasi Geografi (SIG) di SMA Negeri 21 Medan Tahun Ajaran 2017/2018 pada umumnya tergolong pada kategori sedang sebesar $65 \%$ dengan nilai rata-rata 73-105.

2. Terdapat pengaruh yang signifikan Penggunaan internet sebagai sumber belajar terhadap Hasil belajar siswa kelas XII IPS mata pelajaran Geografi pada materi Penginderaan Jauh dan Sistem Informasi Geografi (SIG) di SMA Negeri 21 Medan Tahun Ajaran 2017/2018 dengan hasil $t_{\text {hitung }}$ $>t_{\text {tabel }}(4,233>2,024)$ berarti hipotesis dalam penelitian ini diterima sehingga semakin tinggi penggunaan internet sebagai sumber belajar maka semakin tinggi hasil belajar siswa.

\section{DAFTAR PUSTAKA}

Arikunto, S. (2006). Prosedur Penelitian Suatu Pendekatan Praktik, Ed Revisi VI. Jakarta: PT. Rineka Cipta, 75.

Mudiyanah, 2015. Pengaruh pemanfaatan internet sebagai sumber belajar geografi terhadap hasil belajar siswa: studi pada siswa kelas XI IPS MA Plus Peradaban Insani Yayasan Al-Irnusiyah Batuceper Tangerang. Skripsi. Jakarta. Jurusan Pendidikan Ilmu Pengetahuan Sosial. Fakultas IImu Tarbiyah Dan Keguruan Universitas Islam Negeri (UIN) Syarif Hidayatullah Jakarta.

Damanik, M. R. S., \& Nurman, A. (2016). Pemanfaatan Blog pada Mata Kuliah Sistem Informasi Geografi Jurusan Pendidikan Geografi Fakultas IImu Sosial Universitas Negeri Medan. Jurnal Geografi, 8(1).

Munir. 2008. Kurikulum Berbasis Teknologi Informasi dan Komunikasi. Bandung: Alfabeta

Oetomo, B. S. D. (2002). E-Education (Konsep, Teknologi dan Aplikasi Internet Pendidikan. Andi: Yogyakarta.

Sadiman, Arief. S. 2009. Media pendidikan (Pengertian, Pengembangan, dan pemanfaatannya). Jakarta: Rajawali Pers.

Sudjana, N. (2005). Metode Statistika. Bandung: Tarsito, 168.
Sugiyono. (2008). Metode penelitian pendidikan:(pendekatan kuantitatif, kualitatif dan R \& D). Alfabeta. 